\title{
Prevalensi Sindrom Metabolik pada Pekerja Perusahaan
}

\author{
The Prevalence of Metabolic Syndrome among Company Workers
}

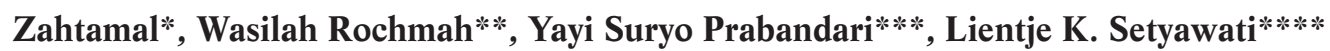

\begin{abstract}
*Bagian Ilmu Kesehatan Masyarakat-Kedokteran Komunitas FK Universitas Riau, **Bagian Ilmu Penyakit Dalam FK Universitas Gadjah Mada, ***Bagian Ilmu Kesehatan Masyarakat FK Universitas Gadjah Mada, ****Program Doktor Ilmu Kedokteran dan Kesehatan FK Universitas Gadjah Mada
\end{abstract}

\begin{abstract}
Abstrak
Sindrom metabolik adalah masalah kesehatan yang prevalensinya cenderung meningkat pada pekerja. Penelitian ini bertujuan memaparkan prevalensi kasus sindrom metabolik yang terjadi pada pekerja perusahaan. Penelitian ini dilakukan pada tahun 2014 pada dua perusahaan di Provinsi Riau dengan rancangan potong lintang. Sumber data adalah rekam medis pekerja yang melakukan medical check up periode Oktober 2013 hingga Februari 2014. Populasi adalah pekerja yang menderita sindrom metabolik sebanyak 131 orang. Sampel penelitian dipilih dengan cara total sampling yakni 131 orang. Instrumen adalah kuesioner, international physical activity questionnaire, tabel 24 hours food recall, dan tabel bantu pencatatan komponen sindrom metabolik. Pengelolaan data dilakukan secara kuantitatif menggunakan analisis univariat dan bivariat, dengan uji korelasi Spearman's Rho dan kai kuadrat. Hasil penelitian mendapatkan prevalensi sindrom metabolik sebanyak $21,58 \%$, dengan jenis kelamin terbanyak adalah laki-laki, kelompok usia terbanyak adalah $>50$ tahun. Sebagian besar kasus sindrom metabolik memiliki tiga komponen, dengan komponen terbanyak adalah lingkar perut dan tekanan darah. Sebanyak 23,50\% kasus memiliki riwayat keluarga obesitas dan diabetes melitus. Sebagian besar kategori aktivitas adalah sedang. Jenis asupan makanan dengan kategori tidak sesuai dengan diet adalah serat pangan dan lemak jenuh. Variabel lingkar perut berhubungan bermakna secara statistik dengan tekanan darah sistolik dan diastolik serta kadar kolesterol high density lipoprotein $(p<0,05)$.
\end{abstract}

Kata kunci: Aktivitas fisik, pekerja perusahaan, prevalensi sindrom metabolik

\section{Abstract}

Metabolic syndrome is a health problem that often occurs among workers. The objective of this research was to reveal prevalence of metabolic syndrome in company workers. This research was conducted in 2014 at two companies in Riau Province with cross sectional design. Data source is the medical records of workers who have been doing medical check up between October 2013 through February 2014. The population is 131 workers who suffer from metabolic syndrome. The study sample is 131 workers, counted by total sampling. The instruments are self-reported questionnaire, international physical activity questionnaire, 24 hours food recall form and recording auxiliary table for components of of metabolic syndrome. Quantitative data management conducted with descriptive analysis and bivariate analysis, by Spearman's Rho correlation test and chi square. Prevalence of metabolic syndrome is $21.58 \%$, with the highest gender is male, and the largest age group is $>50$ years. Most cases of metabolic syndrome has three components, with the largest component is the abdominal circumference and blood pressure. A total of $23.50 \%$ of cases have a family history of obesity and diabetes mellitus. Most categories of activity is moderate. Most types of food intake in the category "out of dietary guidelines" are dietary fiber and saturated fat. Abdominal circumference variable has a statistically significant relationship with systolic and diastolic blood pressure and high density lipoprotein $(p<0.05)$.

Keywords: Physical activity, company workers, prevalence of metabolic syndrome

\section{Pendahuluan}

Data International Labour Organization (ILO) menunjukkan sekitar 160 juta pekerja menjadi sakit karena bahaya di tempat kerja, dan sekitar 2,34 juta meninggal akibat penyakit dan kecelakaan yang berhubungan dengan pekerjaan. ${ }^{1}$ Data National Center for Health

Korespondensi: Zahtamal, Bagian Ilmu Kesehatan Masyarakat-Kedokteran Komunitas Fakultas Kedokteran Universitas Riau. Kampus FK Univ. Riau Lantai 3 Jl. Diponegoro No.1, No.Telp: 0761-839624/839625, e-mail: ta_mal75@yahoo.co.id 
Statistics, Centers for Disease Control and Prevention, dan United States Department of Health and Human Services $^{2}$ menunjukkan pada tahun 2000 jumlah kematian tertinggi berdasarkan penyebab pada pekerja adalah penyakit jantung koroner (710.760 kasus), disusul kanker (553.091 kasus) dan stroke (167.661 kasus). Berdasarkan data ini diketahui bahwa golongan penyakit degeneratif menjadi penyebab utama kematian pekerja.

Salah satu pemicu terjadinya penyakit degeneratif adalah sindrom metabolik. Seseorang dikatakan menderita sindrom metabolik apabila terdapat tiga dari lima kriteria, yaitu obesitas sentral (lingkar perut $\geq 90$ sentimeter untuk pria Asia dan $\geq 80$ sentimeter untuk wanita Asia), trigliserida $\geq 150 \mathrm{mg} / \mathrm{dL}$ atau sedang dalam pengobatan untuk hipertrigliserida, kolesterol high density lipoprotein $(\mathrm{HDL})<40 \mathrm{mg} / \mathrm{dL}$ pada pria dan $<50$ $\mathrm{mg} / \mathrm{dL}$ pada wanita atau sedang dalam pengobatan untuk meningkatkan kadar kolesterol HDL, tekanan darah sistolik $\geq 130 \mathrm{mmHg}$ atau diastolik $\geq 85 \mathrm{mmHg}$ atau sedang dalam pengobatan untuk hipertensi, dan gula darah puasa $\geq 100 \mathrm{mg} / \mathrm{dl}$ atau diabetes melitus tipe $2 .^{3}$

Data epidemiologi menyebutkan bahwa prevalensi sindrom metabolik di dunia adalah 20-25\%. ${ }^{4}$ Prevalensi sindrom metabolik pada pekerja saat ini juga cenderung meningkat. Beberapa hasil penelitian menunjukkan peningkatan kejadian sindrom metabolik di kalangan pekerja. ${ }^{5,6}$ Kejadian sindrom metabolik di kalangan pekerja Indonesia juga cenderung meningkat. Penelitian Semiardji, ${ }^{7}$ menemukan bahwa $24,4 \%$ penyakit di kalangan pekerja adalah terkait sindrom metabolik.

Penyebab sindrom metabolik belum dapat diketahui secara pasti. Suatu hipotesis menyatakan bahwa penyebab primer sindrom metabolik adalah obesitas sentral dan resistensi insulin. ${ }^{4}$ Penyebab lain terdiri dari dislipidemia aterogenik, peningkatan tekanan darah dan kadar glukosa plasma, keadaan prothrombotic, serta proinflamasi. ${ }^{4,8}$

Beberapa faktor perilaku pekerja diketahui juga berkontribusi terhadap timbulnya sindrom metabolik. Faktor tersebut antara lain faktor pekerjaan yang memicu pekerja cenderung untuk berperilaku sedenter (tidak banyak aktivitas fisik), pola makan tidak sehat, perilaku merokok, stres, dan lain-lain. Terkait dengan pola makan, banyak pekerja yang mengeluhkan badannya makin gemuk. Namun, mereka tidak menyadari bahwa asupan kalori terlalu banyak, yang disebabkan mengemil atau makan yang dilakukan terlalu sering.

Selanjutnya, aktivitas fisik di kantor semakin sedikit dibandingkan dengan 50 tahun silam. Hanya 6,5\% orang dewasa yang melakukan aktivitas fisik sambil bekerja. Saat ini, hanya $20 \%$ pekerja yang pekerjaannya membutuhkan aktivitas fisik, menurun dari angka $50 \%$ di era 1960-an. Para pekerja membakar 140 kalori lebih sedikit dibandingkan dengan 50 tahun silam. ${ }^{9}$
Konsekuensi dari masalah kesehatan yang dialami pekerja terutama penyakit degeneratif, merupakan kerugian besar bagi perusahaan. Secara keseluruhan, diperkirakan kerugian yang dialami perusahaan sebagai dampak penyakit akibat kerja dan kecelakaan kerja setiap tahun lebih dari US\$ 2,8 triliun atau sekitar 4\% dari produk domestik bruto. ${ }^{1}$ Dampak buruk akibat sindrom metabolik yang tidak dikelola sangat banyak. Sindrom metabolik merupakan kelompok faktor risiko metabolik dan telah diketahui merupakan faktor risiko multidimensi untuk penyakit kardiovaskuler. ${ }^{4}$

Melihat dampak yang cukup besar baik bagi perusahaan maupun pekerja serta penanganan yang cukup kompleks, diperlukan data dasar atau informasi tentang gambaran kasus sindrom metabolik pada pekerja, terutama di Indonesia. Gambaran kasus ini diharapkan dapat menjadi acuan dalam merancang dan mengimplementasikan program pengelolaan sindrom metabolik, baik dalam bentuk promotif, preventif maupun kuratif, terutama di perusahaan. Adapun tujuan penelitian ini adalah memaparkan prevalensi kasus sindrom metabolik yang terjadi pada pekerja perusahaan.

\section{Metode}

Penelitian ini merupakan studi epidemiologi dengan rancangan potong lintang yang dilakukan untuk memaparkan prevalensi kasus sindrom metabolik yang terjadi pada pekerja perusahaan. Penelitian ini dilakukan pada dua perusahaan di Provinsi Riau pada tahun 2014. Karakteristik jenis pekerjaan yang dilakukan pada dua perusahaan ini adalah pekerjaan yang tidak banyak menggunakan aktivitas fisik pekerjanya. Selain proses kerja yang ditopang oleh teknologi tinggi, juga karena banyak pekerjaan administratif.

Sumber data adalah rekam medis pekerja yang melakukan medical check up periode Oktober 2013 sampai Februari 2014 dengan jumlah 552 data. Penelitian ini dibagi menjadi dua tahap. Tahap pertama untuk mendapatkan prevalensi sindrom metabolik serta distribusinya berdasarkan karakteristik responden dan komponen sindrom metabolik. Selanjutnya, penelitian tahap kedua untuk melihat hubungan variabel perilaku (kebiasaan merokok, aktivitas fisik, pola asupan makanan) dan faktor risiko riwayat keluarga, dengan kejadian sindrom metabolik.

Populasi dalam penelitian ini adalah pekerja yang menderita sindrom metabolik pada dua perusahaan. Kriteria inklusi adalah pekerja yang didiagnosis sindrom metabolik oleh dokter perusahaan dengan kriteria sindrom metabolik menurut International Diabetes Federation (IDF), National Heart, Lung, and Blood Institute (NHLBI), World Heart Federation (WHF), International Atherosclerosis Society (IAS), dan American Heart Association (AHA) tahun 2009. ${ }^{3}$ Data 
rekam medis mencantumkan informasi karakteristik responden (usia, jenis kelamin). Berdasarkan sumber data, didapatkan populasi penelitian tahap satu sebanyak 131 pekerja (109 dari perusahaan A dan 22 dari perusahaan B). Sampel penelitian dipilih dengan cara total sampling yakni 131 orang.

Selanjutnya, dari populasi penelitian tahap satu dipilih secara quota sampling sebanyak 34 responden (14 dari perusahaan A, dan 20 dari perusahaan B) untuk mendapatkan data gambaran perilaku dan faktor risiko terkait dengan sindrom metabolik (penelitian tahap dua). Jumlah ini didasari oleh pendapat Cohen et al, ${ }^{10}$ yang menyatakan bahwa penelitian dengan desain relasional (mengukur hubungan antarvariabel) membutuhkan ukuran sampel minimal adalah 30 .

Instrumen dalam penelitian ini adalah kuesioner (self reported) dan tabel bantu pencatatan komponen sindrom metabolik. Untuk data aktivitas fisik digunakan international physical activity questionnaire, dan untuk data asupan makanan digunakan tabel 24 hours food recall. Pengelolaan dan analisis data dilakukan secara kuantitatif dengan bantuan perangkat lunak pengolahan data komputer. Khusus untuk data asupan makanan diolah dengan menggunakan program nutrisurvey. Hasil pengolahan asupan makanan yang diperoleh dibandingkan dengan acuan asupan makanan bagi penderita gangguan metabolik menurut Perkumpulan Endokrinologi Indonesia (Perkeni) 2011.11

Menurut Perkeni, 11 kategori asupan makanan dikatakan sesuai diet jika asupan asam lemak jenuh < $7 \%$ kebutuhan kalori, asam lemak tak jenuh ganda < $10 \%$ kebutuhan kalori, asam lemak tak jenuh tunggal < $10 \%$ kebutuhan kalori, karbohidrat $45-65 \%$ total asupan energi, protein $10-20 \%$ total asupan energi, serat 25-30 gram per hari, dan kolesterol $<200 \mathrm{mg} /$ hari. Kategori aktivitas fisik menurut Craig et al,12 Dikatakan aktivitas fisik berat jika > 3000 Metabolic Energy Turnover (MET)-menit/minggu, sedang jika 600-2999 MET- menit/minggu, dan ringan jika $<600$ MET-menit/minggu.

Analisis data berupa analisis univariat dalam bentuk distribusi frekuensi, persentase, rerata dan sebaran data. Selanjutnya, analisis bivariat dengan uji korelasi Spearman's Rho (karena data tidak terdistribusi normal). Uji lain untuk melihat hubungan dua variabel kategorik yaitu kai kuadrat atau uji Fisher exact. Penelitian ini menggunakan kemaknaan statistik dengan nilai $\mathrm{p}<$ 0,05 .

\section{Hasil}

Prevalensi kasus sindrom metabolik yang dapat dilaporkan hanya pada perusahaan yang memiliki data lengkap. Berdasarkan pengolahan data diketahui bahwa jumlah pekerja yang yang melakukan medical check up di perusahaan A sebanyak 505 orang. Dari data tersebut, diketahui jumlah pekerja yang menderita sindrom metabolik ada sebanyak 109 orang sehingga didapatkan prevalensi kasus sindrom metabolik pada perusahaan A adalah sebanyak $21,58 \%$.

Selanjutnya, distribusi kasus berdasarkan karakteristik penderita (109 dari perusahaan A, dan 22 dari perusahaan B) dan komponen sindrom metabolik dapat dilihat pada Tabel 1. Berdasarkan pengolahan data variabel usia, diperoleh rerata usia partisipan adalah 49 (2356) tahun. Kelompok usia terbanyak yang menderita sindrom metabolik adalah usia $>50$ tahun dan jenis kelamin terbanyak adalah laki-laki. Sebagian besar penderita sindrom metabolik memiliki jumlah penanda terbanyak yakni tiga komponen (69 orang/52,70\%). Komponen sindrom metabolik terbanyak adalah lingkar perut.

Korelasi antara lingkar perut dengan kadar gula darah puasa dan tekanan darah seperti Tabel 2. Selanjutnya, hubungan antara lingkar perut dengan kondisi dislipidemia yaitu kadar kolesterol HDL dan trigliserida dapat dilihat pada Tabel 3 dan Tabel 4. Berdasarkan uji korelasi, diketahui variabel lingkar perut berkorelasi atau

Tabel 1. Distribusi Frekuensi Kasus Sindrom Metabolik Berdasarkan Karakteristik Penderita dan Komponen Sindrom Metabolik $(n=131)$

\begin{tabular}{llll}
\hline Variabel & Kategori & Jumlah & $\%$ \\
\hline \multirow{2}{*}{ Kelompok usia } & $20-30$ tahun & 12 & 9,20 \\
& $31-40$ tahun & 22 & 16,80 \\
& $41-50$ tahun & 43 & 32,80 \\
Jenis kelamin & $>50$ tahun & 54 & 41,20 \\
& Laki-laki & 124 & 94,70 \\
Jumlah penanda sindrom metabolik & Perempuan & 7 & 5,30 \\
& Penanda 3 & 69 & 52,70 \\
Komponen sindrom metabolik & Penanda 4 & 53 & 40,50 \\
& Penanda 5 & 9 & 6,90 \\
& Lingkar perut (obesitas sentral) & 119 & 90,80 \\
& Kadar gula darah puasa & 77 & 58,80 \\
& Tekanan darah & 96 & 73,30 \\
& Kadar trigliserida & 96 & 73,30 \\
& Kadar kolesterol HDL & 74 & 56,50 \\
\hline
\end{tabular}


Tabel 2. Korelasi antara Lingkar Perut dengan Kadar Gula Darah Puasa dan Tekanan Darah $(\mathbf{n}=131)$

\begin{tabular}{|c|c|c|c|}
\hline \multirow{2}{*}{ Komponen Sindrom Metabolik } & \multicolumn{2}{|c|}{ Lingkar Perut (cm) } & \multirow{2}{*}{ Interpretasi } \\
\hline & $\mathbf{r}$ & $\mathbf{p}$ & \\
\hline Kadar gula darah puasa (mg/dL) & 0,007 & $0,940^{\mathrm{a}}$ & Terdapat korelasi positif (sangat lemah), tetapi tidak bermakna \\
\hline Tekanan darah sistolik (mmHg) & 0,185 & $0,035^{\mathrm{a}}$ & Terdapat korelasi positif (sangat lemah) yang bermakna \\
\hline Tekanan darah diastolik ( $\mathrm{mmHg})$ & 0,185 & $0,035^{\mathrm{a}}$ & Terdapat korelasi positif (sangat lemah) yang bermakna \\
\hline
\end{tabular}

Keterangan: a= diuji dengan Spearman's Rho corellation

Tabel 3. Hubungan antara Lingkar Perut dengan Kolesterol HDL (n = 131)

\begin{tabular}{|c|c|c|c|c|}
\hline \multirow{2}{*}{ Kategori Lingkar Perut } & \multicolumn{2}{|c|}{ Kategori Kolesterol HDL } & \multirow{2}{*}{ Total } & \multirow{2}{*}{ Nilai p } \\
\hline & Tidak Normal & Normal & & \\
\hline Tidak normal & $64(53,8 \%)$ & $55(46,2 \%)$ & $119(100,0 \%)$ & $0,049^{a}$ \\
\hline Normal & $10(83,3 \%)$ & $2(16,7 \%)$ & $12(100,0 \%)$ & \\
\hline Total & $74(56,5 \%)$ & $57(43,5 \%)$ & $131(100,0 \%)$ & \\
\hline
\end{tabular}

Ket: ${ }^{\mathrm{a}}=$ diuji dengan kai kuadrat

Tabel 4. Hubungan antara Lingkar Perut dengan Kadar Trigliserida $(\mathrm{n}=131)$

\begin{tabular}{|c|c|c|c|c|}
\hline \multirow{2}{*}{ Kategori Lingkar Perut } & \multicolumn{2}{|c|}{ Kategori Kadar Trigliserida } & \multirow{2}{*}{ Total } & \multirow{2}{*}{ Nilai $\mathrm{p}$} \\
\hline & Tidak Normal & Normal & & \\
\hline Tidak normal & $86(72,3 \%)$ & $33(27,7 \%)$ & $119(100,0 \%)$ & $0,514^{\mathrm{b}}$ \\
\hline Normal & $10(83,3 \%)$ & $2(16,7 \%)$ & $12(100,0 \%)$ & \\
\hline Total & $96(73,3 \%)$ & $35(26,7 \%)$ & $131(100,0 \%)$ & \\
\hline
\end{tabular}

Ket: $b=$ diuji dengan Fisher exact

berhubungan bermakna secara statistik dengan tekanan darah sistolik dan diastolik, serta kadar kolesterol HDL ( $p>0,05)$. Sementara hubungan antara lingkar perut dengan kadar gula darah puasa dan kadar trigliserida tidak bermakna $(p>0,05)$.

Selanjutnya, dari 131 data responden, telah dipilih sebanyak 34 responden (14 dari perusahaan A, dan 20 dari perusahaan B) untuk menanyakan data perilaku dan faktor risiko terkait dengan kasus sindrom metabolik yang dialami pekerja. Gambaran variabel-variabel tersebut dapat dilihat pada Tabel 5. Berdasarkan pengolahan data diketahui bahwa sebagian besar pekerja yang menderita sindrom metabolik adalah tidak merokok serta tidak memiliki riwayat keluarga obesitas dan diabetes melitus. Dari pengolahan data aktivitas fisik, diketahui bahwa sebagian besar pekerja yang mengalami sindrom metabolik adalah dengan kategori aktivitas fisik yang sedang yakni $61,80 \%$, dengan rerata total aktivitas fisik 1631 MET-menit/minggu. Asupan makanan yang tidak sesuai dengan diet terbesar adalah serat pangan dan asupan lemak jenuh. Rerata jumlah serat pangan yang dikonsumsi oleh pekerja yang menderita sindrom metabolik adalah hanya 8,79 gram/hari. Asupan makanan dengan kategori sebagian besar sudah sesuai dengan diet yaitu asam lemak tak jenuh tunggal (100\%) dan asam lemak tak jenuh ganda $(91,20 \%)$.

\section{Pembahasan}

Berdasarkan pengolahan data diketahui bahwa persentase kasus sindrom metabolik untuk periode tersebut adalah $21,58 \%$, dengan jenis kelamin terbanyak adalah laki-laki. Hasil ini tidak jauh berbeda dengan prevalensi sindrom metabolik dari sumber/data dan hasil penelitian lainnya, salah satunya IDF 4 yang menyebutkan bahwa prevalensi sindrom metabolik dunia adalah 20$25 \%$. Penelitian Nestel et al, ${ }^{13}$ yang mengulas 25 survei sindrom metabolik pada masyarakat Asia (Cina, Hong Kong, Taiwan, Jepang, Filipina dan Singapura) menemukan prevalensi dengan kisaran 10\%-30\%.

Hasil ini juga sejalan dengan penelitian Semiardji, ${ }^{7}$ yang menemukan bahwa sekitar $24,4 \%$ penyakit di kalangan pekerja terkait dengan sindrom metabolik. Selanjutnya, hasil yang sedikit berbeda ditemukan dalam penelitian Windarwati, $1^{4}$ yang menemukan proporsi sindrom metabolik pada perawat yang bekerja pada waktu reguler di RSUP Dr. Sardjito Yogyakarta sebanyak $26,6 \%$.

Rerata usia pekerja yang mengalami sindrom metabolik adalah 49 (23-56) tahun, dengan kelompok usia terbanyak > 50 tahun. Hal ini sejalan dengan pendapat Achmad, ${ }^{15}$ yang mengatakan prevalensi sindrom metabolik meningkat sejalan dengan penambahan usia, dan mengenai lebih dari $40 \%$ mereka yang berusia di 
Tabel 5. Distribusi Frekuensi Kasus Sindrom Metabolik Berdasarkan Variabel Perilaku dan Faktor Risiko Riwayat Keluarga $(n=34)$

\begin{tabular}{lllc}
\hline Variabel Faktor Risiko & Kategori & Frekuensi & Persentase (\%) \\
\hline Kebiasaan merokok & Ya & 8 & 23,50 \\
Riwayat keluarga menderita obesitas & Tidak & 26 & 76,50 \\
& Ya & 8 & 23,50 \\
Riwayat keluarga menderita diabetes melitus & Tidak & 26 & 76,50 \\
& Ya & 8 & 23,50 \\
Aktivitas fisik & Tidak & 26 & 76,50 \\
& Ringan & 8 & 23,50 \\
Asupan makanan & Sedang & 21 & 61,80 \\
Protein & Berat & 5 & 14,70 \\
& & & \\
Karbohidrat & TSDD & 20 & 58,80 \\
\multirow{2}{*}{ Asam lemak jenuh } & SDD & 14 & 41,20 \\
\multirow{2}{*}{ Asam lemak tak jenuh ganda } & TSDD & 25 & 73,50 \\
\multirow{2}{*}{ Asam lemak tak jenuh tunggal } & SDD & 9 & 26,50 \\
\multirow{2}{*}{ Serat pangan } & TSDD & 28 & 82,40 \\
Kolesterol & SDD & 6 & 17,60 \\
& TSDD & 3 & 8,80 \\
& SDD & 31 & 91,20 \\
\hline
\end{tabular}

Ket: TSDD = tidak sesuai dengan diet, SDD = sesuai dengan diet

atas 60 tahun. Lohsoonthorn et al, 6 juga menemukan bahwa kejadian sindrom metabolik lebih banyak terjadi sesuai dengan pertambahan usia pekerja.

Sebagian besar responden memiliki jumlah penanda sindrom metabolik terbanyak yakni tiga komponen, sebagian besar adalah lingkar perut dan tekanan darah. Komponen sindrom metabolik dengan persentase paling sedikit adalah kadar kolesterol HDL. Hasil yang hampir sama ditemukan dalam penelitian Alegria et al, ${ }^{5}$ dan Ervin, 16 yang menemukan bahwa prevelansi penanda sindrom metabolik terbanyak, yaitu tekanan darah tinggi dan lingkar perut/obesitas abdominal/indeks massa tubuh $\geq 28,8 \mathrm{~kg} / \mathrm{m}^{2}$.

Berdasarkan hasil penelitian diketahui variabel lingkar perut berhubungan bermakna secara statistik dengan tekanan darah sistolik dan diastolik, serta kadar kolesterol HDL. Hasil ini memperkuat teori bahwa dengan bertambahnya lingkar perut, otomatis terjadi peningkatan jaringan lemak tubuh. Adiposit jaringan lemak ini adalah adiposit berukuran besar, kurang peka terhadap kerja antilipolisis sehingga lebih mudah dilipolisis yang menyebabkan peningkatan kadar asam lemak bebas. Obesitas yang menyebabkan tingginya asam lemak bebas dalam darah menstimulasi pelepasan sitokin atau produk-produk metabolik yang dapat menurunkan sensitivitas insulin. Sitokin tersebut antara lain sitokin proinflamasi, prokoagulan, peptida inflamasi, dan angiotensinogen. Produk-produk dari sel lemak dan peningkatan asam lemak bebas dalam plasma bertanggung jawab terhadap berbagai penyakit metabolik, seperti diabetes, penyakit jantung, hiperlipidemia, dislipidemia (salah satunya ditandai dengan penurunan kolesterol HDL), gout, dan hipertensi. ${ }^{17}$

Hasil penelitian ini menemukan sebagian besar persentase penderita sindrom metabolik tidak memiliki kebiasaan merokok. Hasil penelitian ini tidak jauh berbeda dari penelitian Lohsoonthorn et al, 6 Pada pekerja di Thailand yang menderita sindrom metabolik, ditemukan $75,4 \%$ tidak pernah merokok. Namun demikian, peneliti berkeyakinan bahwa kebiasaan merokok berkaitan dengan kejadian sindrom metabolik. Merokok bertanggung jawab terhadap mekanisme peningkatan berat badan, kadar kolesterol, aterosklerosis, resistensi insulin, risiko gangguan metabolik dan penyakit kardiovaskuler. ${ }^{18}$ Chiolero et al, ${ }^{19}$ menyatakan bahwa merokok dapat meningkatkan resistensi insulin dan berhubungan dengan akumulasi lemak pusat.

Hasil penelitian ini menemukan penderita sindrom metabolik memiliki riwayat keluarga obesitas dan diabetes melitus masing-masing $23,50 \%$. Hasil ini sejalan dengan pendapat Achmad, 15 yang menyatakan bahwa sekitar 20 - 40\% atau bahkan lebih, masyarakat di berbagai negara dikatakan memiliki kecenderungan genetik memperoleh sindrom metabolik. Beberapa gen yang diteliti berasosiasi dengan obesitas, yaitu gen ob (obesity) yang memproduksi leptin serta gen $d b$ (diabetic) yang memproduksi reseptor leptin.

Dari pengolahan data diketahui bahwa sebagian besar 
kategori dan rerata aktivitas fisik responden adalah rendah sampai sedang. Hasil ini sejalan dengan penelitian Widiantini dan Tafal, ${ }^{20}$ yang menemukan sebagian besar pekerja dengan kategori aktivitas fisik rendah dan sedang. Hasil ini juga mendukung teori tentang hubungan aktivitas fisik dengan kejadian sindrom metabolik. Aktivitas fisik yang kurang (sedentary lifestyle) berhubungan dengan kejadian sindrom metabolik. ${ }^{21}$ Sebaliknya, melalui aktivitas fisik dapat mengubah beberapa faktor risiko antara lain menurunkan kadar low density lipoprotein (LDL) dan trigliserida, meningkatkan kadar high density lipoprotein (HDL), meningkatkan sensitivitas insulin, menurunkan tekanan darah serta faktor-faktor risiko dari penyakit jantung dan penyakit kronis lainnya. Kondisi aktivitas fisik yang kurang pada pekerja ini sejalan dengan penjelasan Nathan dan Delahanty, ${ }^{22}$ bahwa timbulnya perilaku sedenter pada pekerja tidak terlepas dari kemajuan teknologi, informasi dan komunikasi dan ditemukannya alat-alat/mesin canggih pengganti tenaga manusia yang serba otomatis.

Selanjutnya, dari pengolahan data asupan makanan diperoleh sebagian besar kategori tidak sesuai dengan diet adalah serat pangan, asupan lemak jenuh dan karbohidrat. Hasil ini sejalan dengan teori dan hasil penelitian sebelumnya. Beberapa pakar telah menyepakati bahwa diet tinggi lemak dapat meningkatkan total asupan energi dan obesitas. Ma et al, 23 menambahkan bahwa indeks massa tubuh berhubungan dengan indeks glikemik yang terkait dengan diet karbohidrat. Hasil penelitian Sudarminingsih, ${ }^{24}$ pada pekerja PT Unocal Oil Company di Offshore Balikpapan, Kalimantan Timur menemukan bahwa terdapat hubungan yang signifikan antara kejadian sindrom metabolik dengan asupan total karbohidrat $\geq$ $60 \%$ dari total kalori, refined karbohidrat $>5 \%$ dari kalori, dan dari lemak $>20 \%$ dari total kalori.

Selanjutnya, terkait dengan serat pangan, rerata jumlah serat pangan yang dikonsumsi hanya $8,79 \mathrm{~g} /$ hari (idealnya \pm 25 gr/hari). Beberapa faktor yang memungkinkan hal ini antara lain adalah ketersediaan serat dalam pola makan yang masih kurang, responden masih banyak yang makan di luar rumah (seperti di kantin, restoran, dan lain-lain) padahal makanan yang dijual di tempat tersebut sebagian besar masih minim serat, serta kebiasaan makan sayur dan buah (makanan kaya serat) yang belum menjadi menu harian.

Hasil ini juga memperkuat hasil penelitian di Indonesia, bahwa konsumsi serat orang Indonesia ratarata hanya 10,5 gr/hari. ${ }^{18}$ Padahal banyak bukti empiriksdan penelitian yang membuktikan hubungan serat dengan gangguan metabolik, khususnya dalam mencegah komplikasi penyakit degeneratif. Mengonsumsi serat sekitar $35 \mathrm{gr} / \mathrm{hari}$ memiliki risiko terkena penyakit jantung koroner $1 / 3$ lebih rendah dibandingkan dengan orang yang mengonsumsi serat kurang 15 gr/hari.
Berdasarkan uraian di atas, dapat dikatakan bahwa sindrom metabolik merupakan hasil interaksi antara gangguan genetik dengan perubahan gaya hidup. Sindrom metabolik akan muncul saat seorang dengan kecenderungan genetik mengalami obesitas. Ilustrasi pernyataan ini adalah kenyataan bahwa tidak semua individu dengan overweight atau obesitas mengalami sindrom metabolik karena masih ada kemungkinan dua faktor lain yang berperan, yaitu kecenderungan genetik dan resistensi insulin. Bukti lain adalah adanya perbedaan kecenderungan terhadap faktor risiko metabolik dan bentuk kelainannya pada kelompok etnis yang berbeda.

Pada beberapa populasi di Asia Selatan, ditemukan tingginya prevalensi sindrom metabolik kendati dengan obesitas rendah, yang menunjukkan tingginya peran kecenderungan genetik. Kompleksnya pengaturan jalur metabolisme memberikan alasan besarnya peran kecenderungan genetika pada variasi bentuk sindrom metabolik. Oleh karena itu, variasi genetika memiliki hubungan yang erat dengan obesitas dalam menentukan sindrom metabolik. Apabila demikian, patogenesis sindrom metabolik tidak akan dapat dijelaskan secara menyeluruh sebelum dasar variasi genetiknya dapat terungkap. ${ }^{15}$

Obesitas sendiri tidak selalu menyebabkan kelainan metabolisme dan tidak semua penderita kelainan metabolisme mengalami obesitas. Beberapa studi telah dilakukan untuk mendukung konsep yang disebut adiposopathy, yaitu beberapa kelainan metabolisme bukan karena kelebihan jaringan lemak itu sendiri, tetapi adanya disfungsi jaringan lemak. Keadaan ini perlu identifikasi mekanisme akar dari penyebab kelainan metabolisme glukosa, lemak dan hipertensi yang kemungkinan secara genetik termasuk rentan. Kondisi tersebut dapat dibuktikan dari hasil penelitian di United State of America (USA) yang menyatakan bahwa hanya 12\% pasien dengan IMT $27 \mathrm{~kg} / \mathrm{m}^{2}$ menderita diabetes melitus tipe 2. Sebaliknya, $67 \%$ pasien diabetes melitus tipe 2 mempunyai IMT $27 \mathrm{~kg} / \mathrm{m}^{2}$, sementara $46 \%$ mempunyai IMT $30 \mathrm{~kg} / \mathrm{m}^{2}$. Peneliti lain membuktikan bahwa tidak semua pasien yang kelebihan berat badan mengalami hipertensi, dan tidak semua pasien hipertensi kelebihan berat badan. Disimpulkan bahwa peningkatan lemak tubuh berisiko terhadap timbulnya hipertensi, tetapi peningkatan berat badan secara sendiri tidak cukup menyebabkan berkembangnya hipertensi. Penyebab obesitas sebagai komponen sindrom metabolik, sangatlah kompleks dan multifaktor, meliputi faktor genetika dan lingkungan. 25

\section{Kesimpulan}

Berdasarkan hasil penelitian diketahui bahwa prevalensi kasus sindrom metabolik pada pekerja adalah $21,98 \%$, dengan jenis kelamin terbanyak adalah laki-laki, rerata usia pekerja 49 tahun, dan kelompok usia ter- 
banyak adalah usia $>50$ tahun. Sebagian besar pekerja penderita sindrom metabolik adalah dengan tiga komponen, dengan komponen yang terbanyak adalah lingkar perut dan tekanan darah. Dari pengolahan data aktivitas fisik, diketahui bahwa sebagian besar pekerja yang mengalami sindrom metabolik adalah dengan rerata dan kategori aktivitas fisik yang rendah sampai sedang. Selanjutnya, asupan makanan pekerja sindrom metabolik dengan kategori tidak sesuai dengan diet adalah serat pangan, lemak jenuh dan karbohidrat. Berdasarkan hasil penelitian diketahui variabel lingkar perut berkorelasi atau berhubungan bermakna secara statistik dengan TDS dan TDD, serta kadar kolesterol HDL.

\section{Saran}

Beberapa hal yang disarankan kepada pihak perusahaan antara lain merancang dan mengoptimalkan pengelolaan sindrom metabolik di perusahaan melalui kegiatan occupational health (terutama promosi kesehatan di tempat kerja dengan melibatkan seluruh komponen, yakni pekerja sebagai sasaran utama serta pimpinan perusahaan, serikat pekerja dan keluarga) karena kasus sindrom metabolik cenderung meningkat dan sudah mulai terjadi pada usia pekerja yang relatif muda. Upaya yang perlu dilakukan atau dioptimalisasi adalah pengelolaan gizi (penataan gizi dengan menyediakan makanan dengan sistem rantang yang sudah ditentukan komposisinya dan dihitung jumlah kalorinya atau sesuai dengan kebutuhan diet dan gangguan kesehatan yang ada), program peningkatan aktivitas/latihan fisik serta penghentian perilaku merokok pada pekerja.

\section{Ucapan Terima Kasih}

Dalam kesempatan ini peneliti mengucapkan terima kasih kepada Direktorat Jenderal Pendidikan Tinggi yang telah membantu pembiayaan penelitian.

\section{Daftar Pustaka}

1. International Labour Organizatation. The prevention occupational diseases-2 million workers killed every year [internet]. World Day for safety and health at work. 2013 [cited 2014 Jan 10]. Available from: http://www.ilo.org/wcmsp5/groups/public/edprotect/protrav/safework/documents/publication/wcms208226.pdf

2. National Alliance for Nutrition and Activity (NANA). Obesity and other diet-and inactivity-related diseases; national impact, costs, and solution. Nutrition policy [internet]. 2003 [cited 2011 May 11]. Available from:http://www.spencer.k12.ia.us /pages/hs_library/NANA advocatesnationalpolicies.pdf.

3. Alberti KG, Eckel RH, Grundy SM, Zimmet PZ, Cleeman JI, Donato KA, et al. Harmonizing the metabolic syndrome. Circulation. 2009; 120:1640-5.

4. International Diabetes Federation [homepage in internet]. The IDF consensus worldwide definition of the metabolic syndrome. 2006 [cited 2011 may 20]. Available from: http://www. idf .org.
5. Alegría E, Cordero A, Laclaustra M, Grima A, León M, Casasnovas JA. Prevalence of metabolic syndrome in the Spanish working population: MESYAS registry. Revista Española de Cardiología. 2005; 58 (7): $797-$ 806.

6. Lohsoonthorn V, Lertmaharit S, Williams MA. Prevalence of metabolic syndrome among profesional and office workers in Bangkok, Thailand. Journal of the Medical Association of Thailand. 2007; 90 (9): 19081915.

7. Semiardji G. The prevalence of the metabolic syndrome: Findings from the epidemiological study on obesity and its comorbidities in Indonesian populations. In: Tjokroprawiro A, Soegih R, Soegondo S, Wijaya A, Sutardjo B, Tridjaja B, et al, eds. Proceedings of The 3 National Obesity Symposium. Hotel Shangri La Jakarta, 15-16 Mei 2004. Jakarta: Indonesian Society for the Study on Obesity; 2004.

8. Thaman RG, Arora GP. Metabolic syndrome: definition and pathophysiology- the discussion goes on. Journal of Physiology and Pharmacology Advances. 2013; 3 (3): 48-56.

9. Church TS, Thomas DM, Tudor-Locke C, Katzmarzyk PT, Earnest CP, Rodarte RQ, et al. Trends over 5 decades in U.S. occupation-related physical activity and their associations with obesity. PLoS ONE. 2011; 6(5): e19657. doi:10.1371/journal.pone.0019657.

10. Cohen L, Manion L, Morrison K. Research methods in education. 6th ed. London: Routledge, 2007.

11. Perkeni. Konsensus - Pengelolaan dan pencegahan diabetes mellitus tipe 2 di Indonesia. Jakarta: Pengurus besar perkumpulan endokrinologi Indonesia (PB Perkeni); 2011.

12. Craig CL, Marshall AL, Sjostro MM, Bauman AE, Booth ML, Ainsworth $\mathrm{BE}$, et al. International physical activity questionnaire: 12-country reliability and validity. Medicine and Science in Sports and Exercise. 2003; 35: 1381-95.

13. Nestel P, Lyu R, Low LP, Sheu WHH, Nitiyanant W, Saito I, et al. Metabolic syndrome: recent prevalence in East and Southeast Asian populations. Asia Pacific Journal of Clinical Nutrition. 2007; 16 (2): 362-7.

14. Windarwati. Sindrom metabolik perawat shift dan perawat reguler di RSUP DR. Sardjito tahun 2010 [tesis]. Yogyakarta : Universitas Gajah Mada; 2011.

15. Achmad TH. Metabolic syndrome and diabetic vascular disease. Endokrinologi Klinik. Bandung: Perhimpunan Endokrinologi Indonesia Cabang Bandung; 2004.

16. Ervin RB. Prevalence of metabolic syndrome among adults 20 years of age and over, by sex, age, race and ethnicity, and body mass index: United States, 2003-2006. Nat Health Stat Reports [serial on internet]. 2009 May [cited 2013 Jan 20]; 13. Available from: http://www.ncbi.nlm.nih .gov/pubmed/19634296.

17. Jalal F, Liputo NI, Susanti N, Oenzil F. Lingkar pinggang, kadar glukosa darah, trigliserida dan tekanan darah pada etnis Minang di Kabupaten Padang Pariaman, Sumatera Barat. Media Medika Indonesiana. 2008; 43 (3): $129-36$

18. Handajani A, Roosihermiatie B, Maryani H. Factors associated with mortality pattern of degenerative diseases in Indonesia. Bulletin Penelitian Sistem Kesehatan. 2010; 13 (1): 42-53.

19. Chiolero A, David F, Fred P, Jacques C. Consequences of smoking for body weight, body fat distribution, and insulin resistence. The American Journal of Clinical Nutrition. 2008; 87: 801-9. 
20. Widiantini W, Tafal Z. Aktivitas fisik, stres, dan obesitas pada pegawai negeri sipil. Jurnal Kesehatan Masyarakat Nasional. 2014; 8 (7): 3306.

21. Bertrais S, Beyeme-Ondoua JP, Czernichow S, Galan P, Hercberg S, Oppert JM. Sedentary behaviors, physical activity, and metabolic syndrome in middle-aged French subjects. Obesity Research. 2005; 13: 936 -944 .

22. Nathan DM, Delahanty LM. Conquering diabetes. Dalam: Tjandrasa M, penterjemah. Jakarta: PT. Bhuana Ilmu Populer; 2009.
23. Ma Y, Bertone ER, Stanek EJ, Reed GW, Hebert JR, Cohen NL, et al. Association between eating patterns and obesity in a free-living US adult population. American Journal of Epidemiology. 2003; 158 (1): 85-92.

24. Sudarminingsih S. Hubungan pola makan dengan sindrom metabolik pada karyawan PT Unocal Oil Company di offshore Balikpapan propinsi Kalimantan Timur [tesis]. Yogyakarta: Universitas Gajah Mada; 2007.

25. Sargowo D, Andarini S. The relationship between food intake and adolescent metabolic syndrome. Jurnal Kardiologi Indonesia. 2011; 32: 1423. 